\title{
Activation of Rabbit Hageman Factor by Homogenates of Cultured Rabbit Endothelial Cells
}

\author{
Roger C. Wiggins, David J. Loskutoff, Charles G. Cochrane, John H. Griffin, \\ and Thomas S. EDGington, Departments of Immunopathology and Molecular \\ Immunology, Research Institute of Scripps Clinic, La Jolla, California 92037
}

A B S T R A C T Rabbit Hageman factor was proteolytically cleaved and activated by a homogenate prepared from cultured rabbit endothelial cells. Cleavage of radiolabeled Hageman factor was monitored by polyacrylamide gel electrophoresis in the presence of sodium dodecyl sulfate. Endothelial cell-mediated cleavage of Hageman factor was demonstrated both in a purified system and in plasma, was time and concentration dependent, and was associated with formation of the characteristic $28,000 M_{\mathrm{r}}$ form of active Hageman factor. The rate of cleavage of Hageman factor was not affected by Triton X-100 (Rohm and Haas, Co., Philadelphia, Pa.), hexadimethrine bromide (Polybrene, Aldrich Chemical Co., Inc., Milwaukee, Wis.), hirudin, soybean trypsin inhibitor, or antisera to plasminogen or prekallikrein. However, cleavage was enhanced by kaolin, and was inhibited by diisopropylfluorophosphate. The enzyme responsible for cleavage of Hageman factor was localized to the 100,000-g-sedimentable, subcellular fraction of the endothelial cell homogenate and was relatively specific, because neither radiolabeled rabbit Factor XI nor rabbit prekallikrein were themselves proteolytically cleaved by the endothelial cell homogenate. However, when these molecules were incubated with the homogenate in the presence of Hageman factor, both Factor XI and prekallikrein were cleaved, demonstrating that Hageman factor had been activated by the endothelial cell homogenate. Furthermore, the kallikrein generated by endothelial cell homogenate-activated Hageman factor was capable of liberating kinin from high molecular weight kininogen as measured by bioassay. Cultured rabbit endothelial cells, therefore, possess the capacity

This is publication 1731 from the Departments of Immunopathology and Molecular Immunology, Scripps Clinic and Research Foundation, La Jolla, Calif.

A preliminary report of this work was presented at the Meeting of the American Hematology Society, New Orleans, La. 1978. Blood. 52(Suppl. I): 371. (Abstr.)

Received for publication 25 April 1979 and in revised form 5 September 1979. to activate Hageman factor by proteolysis. This may be one mechanism for Hageman factor activation in vivo.

\section{INTRODUCTION}

The blood is enveloped by a continuous layer of endothelial cells lining the complex ramifications of the vascular system. These cells represent the anatomical barrier and an apparently important interface between blood and contiguous tissues. The compatibility of the intact endothelial cell surface with blood and its constituent procoagulant proteins is a central and necessary condition for maintenance of vascular homeostasis. Although the mechanism of this compatibility has not been fully elucidated, it is clear that the production by endothelial cells of fibrinolytic enzymes $(1,2)$, prostacyclin (3), and other factors that influence platelet function $(4,5)$ or vascular tone $(6)$ may play a significant role in ensuring vessel patency. The endothelial cell surface is equally important in hemostasis and the induction of thrombus formation inasmuch as damage to this layer is associated with attachment of platelets and the initiation of coagulation (7). Although it is tacitly accepted that coagulation is initiated by contact with constituents of the subendothelium, the possibility that the endothelial cell per se participates in the initiation or modification of procoagulant events should not be overlooked.

In our study, we have employed cultured rabbit endothelial cells as a model to explore the role of the endothelium in the initiation of the intrinsic procoagulant pathway. Here we provide evidence that these cells possess an enzyme that can activate rabbit Hageman factor $(\mathrm{HF} \text {, blood coagulation Factor XII })^{1}$ by

\footnotetext{
${ }^{1}$ Abbreviations used in this paper: EC, endothelial cell; $\mathrm{HF}$, Hageman factor; $\mathrm{HF}_{\mathrm{a}}$, activated $\mathrm{HF} ; \alpha-\mathrm{HF}_{\mathrm{a}}$, the 82,000 $M_{\mathrm{r}}$ form of $\mathrm{HF}_{\mathrm{a}} ; \boldsymbol{M}_{\mathrm{r}}$, molecular weight; SBTI, soybean trypsin inhibitor; SDS-PAGE, polyacrylamide gel electrophoresis in the presence of sodium dodecyl sulfate; TBS, Tris-buffered saline.
} 
proteolysis, and thereby lead to activation of the coagulation, kallikrein, and kinin-forming pathways.

\section{METHODS}

\section{Purified proteins from rabbit plasma}

Hageman factor. HF was purified from rabbit plasma either by the method of Griffin and Cochrane $(8,9)$ or by affinity chromatography using anti-rabbit $\mathrm{HF}$ immobilized on Sepharose 4B (Pharmacia Fine Chemicals, Div. of Pharmacia Inc., Piscataway, N. J.) and subsequent elution of HF with $5 \mathrm{M}$ guanidine followed by DEAE- and SP-Sephadex (Pharmacia Fine Chemicals) ion exchange chromatography. ${ }^{2}$ HF prepared by both techniques was the same with respect to specific clotting activity ( 86 clotting $\mathrm{U} / \mathrm{mg}$ protein in human HF-deficient plasma), migration on polyacrylamide gels in the presence of sodium dodecyl sulfate (a single-chain polypeptide with an apparent $M_{\mathrm{r}}$ of 82,000 ), cleavage fragments generated in kaolin-activated rabbit plasma $(52,000,50,000$, and 28,000 $M_{\mathrm{r}}$ ), and half-life of radiolabeled $\mathrm{HF}$ in rabbits $(28-31 \mathrm{~h})$. The $82,000 M_{\mathrm{r}}$ form of activated Hageman factor $\left(\alpha-\mathrm{HF}_{\mathrm{a}}\right)$ preparation ${ }^{2}$ was a single polypeptide chain of 82,000 $M_{\mathrm{r}}$ on sodium dodecyl sulfate polyacrylamide slab gel electrophoresis (SDS-PAGE) under nonreducing conditions, but $82 \%$ of the protein dissociated into fragments of 50,000 and $28,000 M_{\mathrm{r}}$ in the presence of reducing agents. The specific clotting activity was 1.6 -fold greater than that of single-chain HF. Prekallikrein (kindly provided by Dr. Richard Ulevitch, Research Institute of Scripps Clinic), Factor XI, and high $M_{r}$ kininogen were purified from citrated rabbit plasma as previously reported (10-12). Factor XI and prekallikrein migrated as homogeneous single-protein bands on SDS-PAGE in the presence and absence of reducing agents. The high $M_{\mathrm{r}}$ kininogen preparation was heterogeneous by this criterion, with major protein bands observed at 110,000 and 70,000 $M_{\mathrm{r}}$ in the presence of reducing agents. The specific clotting activity of high $M_{\mathrm{r}}$ kininogen preparation assayed in high $\boldsymbol{M}_{\mathrm{r}}$ kininogen-deficient plasma (Fitzgerald trait) was $9 \mathrm{cu} / \mathrm{mg}$ of protein. ( $1 \mathrm{cu}$ is defined as the amount of activity present in $1 \mathrm{ml}$ of normal citrated rabbit plasma.)

Cell culture. Endothelial cells (EC) were isolated from intact rabbit vena cava as previously described (1), and grown on Falcon disposable plasticware (Falcon Labware, Div. of Becton Dickinson \& Co., Oxnard, Calif.) in modified Eagle's medium (with Earle's salts) supplemented with fetal bovine serum $(10 \%)$, streptomycin $(100 \mu \mathrm{g} / \mathrm{ml})$, and penicillin $(100$ $\mathrm{U} / \mathrm{ml}$ ). All culture media and supplements were from Grand Island Biological Co., Grand Island, N. Y. Cultures were maintained at $37^{\circ} \mathrm{C}$ in a $95 \%$ air, $5 \% \mathrm{CO}_{2}$ atmosphere. EC were routinely subcultured once a week (1:5), after trypsinization (Grand Island Biological Co., 0.25\% for 5-10 min) of confluent monolayers. All cells used in these studies had been subcultured 8-20 times. Confluent cultures were well contact inhibited, could not be stimulated to divide with fresh serum, and continued to express morphological and biochemical properties of the intact endothelium (13). Rabbit intimal cells were kindly provided by Dr. B. Bounassisi, University of California at San Diego, and rabbit aortic smooth muscle cells were isolated as described (14).

Preparation of cell homogenates and subcellular fractions. Cultures were washed three times with cold phosphate-buf-

\footnotetext{
${ }^{2}$ Wiggins, R. C., and C. G. Cochrane. Rabbit Hageman factor. Activation of prekallikrein and Factor XI by $\alpha-H_{\mathrm{a}}$. The role of the negatively charged surface. Submitted for publication.
}

fered saline and removed from the surface of the Petri dish with a rubber policeman. The cells were washed again by centrifugation at $800 \mathrm{~g}$ for $5 \mathrm{~min}$, and the cell pellets were resuspended in cold hypotonic homogenization medium $(0.25$ $\mathrm{M}$ sucrose, $1 \mathrm{mM}$ EDTA, $0.01 \mathrm{M}$ Tris- $\mathrm{HCl}, \mathrm{pH} 8.1$ ) at $4^{\circ} \mathrm{C}$ and homogenized with a tight-fitting, Teflon pestle tissue grinder (Arthur H. Thomas Co., Philadelphia, Pa.) until 90$95 \%$ of the cells were disrupted. The nuclei were removed by centrifugation at $600 \mathrm{~g}$ for $10 \mathrm{~min}$, and the supernate was centrifuged at $100,000 \mathrm{~g}$ for $60 \mathrm{~min}$ to yield a cytosol and a particulate fraction.

SDS-PAGE and autoradiography. SDS-PAGE was performed according to Laemmli (15). The stacking and running gels contained 4 and $10 \%$ acrylamide, respectively. The samples were boiled for $4 \mathrm{~min}$ in the presence of $2 \%$ sodium dodecyl sulfate and $2.5 \% \beta$-mercaptoethanol and then applied to the gel. After electrophoresis, the gels were fixed and stained in $50 \%$ trichloroacetic acid and $0.1 \%$ Coomassie Brilliant Blue R250 (Bio-Rad Laboratories, Richmond, Calif.), destained in $10 \%$ glacial acetic acid, dried with a Slab Gel Drier (Hoefer Scientific Instruments, San Francisco, Calif.). and placed on Kodak X-omatic film (Eastman Kodak Co., Rochester, N. Y.) to localize the radiolabeled protein. Molecular weights of radiolabeled proteins were determined from the relative migration of internal standard proteins analyzed on the same gel. The radioactivity on the gel was quantitated by slicing the gel and counting the radioactivity in each slice. The percent of proteolytic cleavage of radiolabeled proteins was calculated by determining the proportion of total radioactivity in the gel that remained at the native molecular weight after treatment and comparing it with that in the control. In all cases, at least $70 \%$ of the radioactivity in control gels was at native molecular weight.

HF-depleted rabbit plasma. HF-depleted rabbit plasma was prepared using an insolubilized IgG fraction of monospecific goat anti-rabbit $\mathrm{HF}$ as described elsewhere (11). HFdepleted plasma was reconstituted by adding sufficient purified HF back to the depleted plasma to normalize the clotting time.

Kinin bioassay. 200-g, virgin, female Brown Norway rats were injected intramuscularly with diethylstilbestrol (100 $\mu \mathrm{g}$ in mineral oil) $18 \mathrm{~h}$ before assay. The uterus was removed, and a single uterine horn used in a Schultz-Dale constanttemperature apparatus for kinin assay. Synthetic bradykinin (Sandoz Inc., East Hanover, N. J.) was used as a standard. The results were quantitated by measuring the time from stimulus to contraction. A linear relationship was observed between the log of the bradykinin concentration and the log of the time between stimulus and contraction. The results were expressed as bradykinin equivalents in nanograms.

Miscellaneous. All chemicals and reagents used were of the highest grade available. Protein determinations were made by the method of Lowry et al. (16) using bovine serum albumin (Sigma Chemical Co., St. Louis, Mo.) as a standard. Radiolabeling of protein with ${ }^{125} \mathrm{I}$ was performed by the chloramine-T method (17) to a specific activity of $1-3 \mu \mathrm{Ci} / \mu \mathrm{g}$. After radiolabeling, the protein solutions were dialyzed against

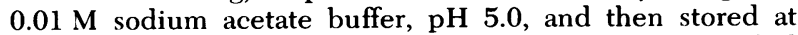
$-20^{\circ} \mathrm{C}$. After radiolabeling, as much as $7 \%$ of the radiolabel migrated at the $28,000 M_{\mathrm{r}}$ position on SDS-PAGE. Radioactivity was measured in a Packard Gamma Spectrometer (Packard Instrument Co., Inc., Downers Grove, Ill.). Human HF-deficient plasma was purchased from George King Biomedical, Inc., Overland Park, Kansas. Human $\alpha$-thrombin was a generous gift of Dr. J. Fenton, Division of Laboratories and Research, New York State Department of Health, Albany. Hirudin and soybean trypsin inhibitor were purchased from Sigma Chemical Co. Diispropylfluorophosphate was purchased from 


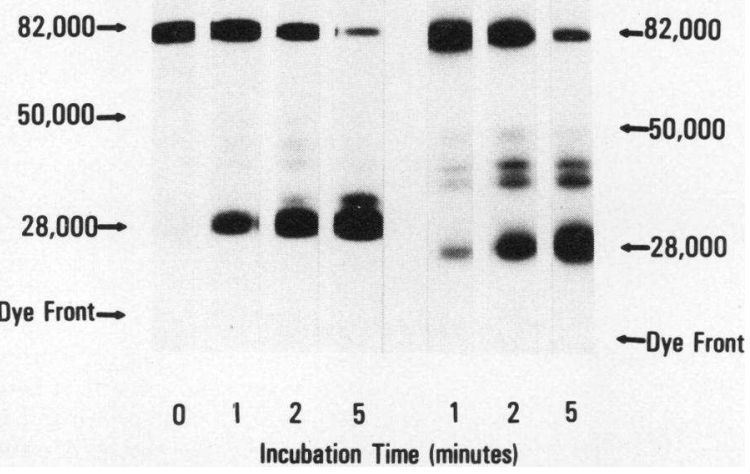

FIGURE 1 SDS-PAGE autoradiograms of ${ }^{125}$ I-HF exposed to EC homogenate analyzed under reducing and nonreducing conditions. ${ }^{125} \mathrm{I}-\mathrm{HF}(1.3 \mu \mathrm{g})$ was incubated at $37^{\circ} \mathrm{C}$ with EC homogenate $(480 \mu \mathrm{g})$ in the presence of $0.01 \mathrm{M}$ Tris, $\mathrm{pH} 7.4$, and bovine serum albumin $(40 \mu \mathrm{g})$ in a final reaction

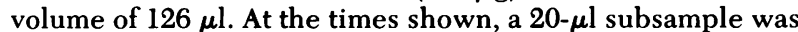
removed and boiled in the presence of $20 \mu \mathrm{l} 5 \%$ sodium dodecyl sulfate for $4 \mathrm{~min}$. $20 \mu \mathrm{\mu}$ of this mixture was then removed and boiled for $2 \mathrm{~min}$ in the presence of $\beta$-mercaptoethanol. The reduced and nonreduced mixtures were analyzed separately by SDS-PAGE and autoradiography as described in Methods.

Calbiochem-Behring Corp., American Hoechst Corp., San Diego, Calif. The angiotensin-converting enzyme inhibitor SQ 20881 was generously provided by Dr. W. B. McDowell, The Squibb Institute for Medical Research, Princeton, N. J.

\section{RESULTS}

Cleavage of HF in the presence of EC homogenates. Incubation of ${ }^{125} \mathrm{I}-\mathrm{HF}$ with the EC homogenate prepared from cultured cells resulted in proteolytic cleavage of the native $82,000 M_{\mathrm{r}}{ }^{125} \mathrm{I}-\mathrm{HF}$ molecule as shown in Fig. 1. In the presence and in the absence of reducing agents, the dominant cleavage fragment had an estimated $M_{\mathrm{r}}$ of about 28,000 and in independent experiments was observed to comigrate with the $28,000 M_{\mathrm{r}}$ fragment generated in kaolin-activated, citrated, normal rabbit plasma. This finding is compatible with the concept that the $28,000 M_{\mathrm{r}}$ fragment $\left(\beta-\mathrm{HF}_{\mathrm{a}}\right)$ is being generated under these conditions. Further support for this concept came from using preparations of ${ }^{125} \mathrm{I}-\mathrm{HF}$ with low specific activity $(0.2 \mu \mathrm{Ci} / \mu \mathrm{g})$, in which the ${ }^{125} \mathrm{I}$ was predominantly $\left(>72 \%\right.$ ) attached to the $28,000 M_{\mathrm{r}}$ fragment when assessed in kaolin-activated, normal rabbit plasma. In the presence of the EC homogenate, the appearance of the major band of cleaved ${ }^{125} \mathrm{I}-\mathrm{HF}$ at the $28,000 M_{\mathrm{r}}$ position indicated that this fragment originated from that portion of the HF molecule known to contain the active site serine. Additional cleavage fragments of ${ }^{125} \mathrm{I}-\mathrm{HF}$ were observed at 46,000 and 41,000 $M_{\mathrm{r}}$ (Fig. 1). If the ${ }^{125} \mathrm{I}-\mathrm{HF}$ was first preincubated with kaolin to permit surface binding and was then incubated with the cell homogenate, a greater proportion of the $50,000 M_{r}$ cleavage fragment was observed on reduced gels (data not shown). This fragment migrated in the same position as the heavy chain HF fragment generated in kaolin-activated, normal rabbit plasma.

The effect of the EC homogenate upon ${ }^{125} \mathrm{I}-\mathrm{HF}$ added to rabbit plasma in the presence or absence of kaolin is shown in Fig. 2. In two separate experiments, EC homogenate alone induced cleavage of only $3-5 \%$ of the ${ }^{125}$ I-HF (lane 2). Addition of kaolin alone resulted in $10 \%$ cleavage (lane 3 ). However, in the presence of both the EC homogenate and kaolin, $>35 \%$ of the molecules were cleaved (lane 4) over the same time interval. The cleavage fragments of ${ }^{125} \mathrm{I}-\mathrm{HF}$ observed under these conditions were at 50,000 and $28,000 M_{\mathrm{r}}$. The difference in the patterns of cleavage observed in Figs. 1 and 2 may have been the result of the EC homogenate enhancing reciprocal activation between $\mathrm{HF}$ and prekallikrein in kaolin-activated plasma.

Rate of cleavage of $H F$ by the EC homogenate. The rate of conversion of native ${ }^{125} \mathrm{I}-\mathrm{HF}\left(82,000 M_{\mathrm{r}}\right)$ to the $28,000 M_{\mathrm{r}}$ fragment were measured during a 20 min incubation at $37^{\circ} \mathrm{C}$ (Fig. 3). The disappearance of native $\mathrm{HF}$ was rapid ( $50 \%$ in $2-3 \mathrm{~min}$ ). There was a concomitant increase in radioactivity in the 28,000 $M_{\mathrm{r}}$ region of the gel, indicating that the ${ }^{125} \mathrm{I}-\mathrm{HF}$ was undergoing time-dependent proteolytic cleavage to yield the $28,000 M_{\mathrm{r}}$ fragments. Other fragments, as shown in Fig. 1, were also generated during the incubation.

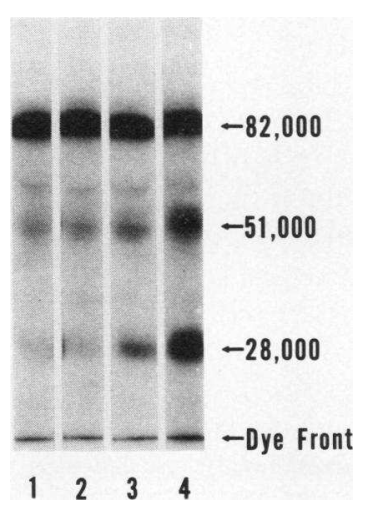

FIGURE 2 SDS-PAGE autoradiogram of ${ }^{125} \mathrm{I}-\mathrm{HF}$ in rabbit plasma exposed to EC homogenate for $10 \mathrm{~min}$ at $37^{\circ} \mathrm{C} .{ }^{125} \mathrm{I}$ HF ( $150 \mathrm{ng}$ ) in citrated rabbit plasma ( $15 \mu \mathrm{l}$ of $25 \%$ plasma in Tris-buffered saline [TBS]) was incubated in the presence of TBS alone (lane 1), the EC homogenate (130 $\mu \mathrm{g}$ of cellular protein) (lane 2), kaolin (40 $\mu \mathrm{g}$ ) (lane 3), or kaolin with EC homogenate (lane 4). The mixtures were analyzed by SDSPAGE and autoradiography. 


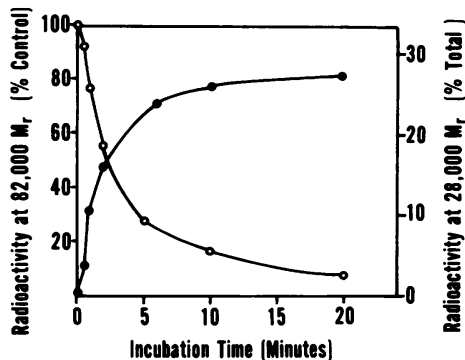

FIgURE 3 Rate of cleavage of $\mathrm{HF}$ by EC homogenate. ${ }^{125} \mathrm{I}-\mathrm{HF}(1.2 \mu \mathrm{g})$ in $100 \mu \mathrm{l} 0.1 \mathrm{M}$ Tris buffer, $\mathrm{pH} 7.4$, containing bovine serum albumin $(1 \mathrm{mg} / \mathrm{ml})$ was incubated with EC homogenate $(450 \mu \mathrm{g}$ of cellular protein). Aliquots $(10 \mu \mathrm{l})$ were removed at the times shown and analyzed by SDS-PAGE. The bands visualized by autoradiography were excised and counted for radioactivity. The disappearance of radioactivity from the $82,000 M_{\mathrm{r}}$ band $(0)$ was associated with the appearance of radioactivity at $28,000 M_{\mathrm{r}}(\odot)$.

Comparative effects of EC homogenate on radiolabeled $H F$, prekallikrein, and Factor XI. To assess the substrate specificity of the HF-cleaving activity, the effect of EC homogenate on prekallikrein and Factor XI was examined. ${ }^{125}$ I-Prekallikrein (280 ng), ${ }^{125} \mathrm{I}-$ Factor XI (200 $\mathrm{ng}$ ), and ${ }^{125} \mathrm{I}-\mathrm{HF}$ (200 $\mathrm{ng}$ ) were incubated separately with the EC homogenate (430 $\mu \mathrm{g}$ ) for $20 \mathrm{~min}$ at $37^{\circ} \mathrm{C}$ in a final volume of $52 \mu \mathrm{l}$ and

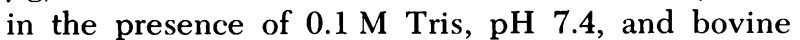
serum albumin $(10 \mu \mathrm{g})$. Aliquots $(10 \mu \mathrm{l})$ were removed at intervals for analysis by SDS-PAGE. After 1, 5, and $20 \mathrm{~min}$ of incubation, the relative proportion of molecules cleaved were: Factor XI-0, 0, 0\%; prekallikrein-0, 0, $0 \%$; and Hageman factor-22, 59, 78\%, respectively. Thus, under these conditions, only the ${ }^{125} \mathrm{I}-\mathrm{HF}$ underwent proteolytic cleavage. The ${ }^{125} \mathrm{I}$ prekallikrein and Factor XI (which were present at the same molar concentrations as $\mathrm{HF}$ ) remained at their native position. In control experiments, the ${ }^{125} \mathrm{I}$ prekallikrein and ${ }^{125} \mathrm{I}$-Factor XI were shown to be cleaved normally in kaolin-activated rabbit plasma. In experiments using higher concentrations of the EC homogenate $(>20 \mathrm{mg} / \mathrm{ml}$ cellular protein) no more than $5 \%$ of the ${ }^{125} \mathrm{I}$-Factor XI or ${ }^{125} \mathrm{I}$-prekallikrein molecules were cleaved in $20 \mathrm{~min}$. This specificity of the EC homogenate contrasts sharply with that of trypsin. ${ }^{125} \mathrm{I}-\mathrm{HF}$ and ${ }^{125} \mathrm{I}$-prekallikrein, under conditions similar to those described above, were equally sensitive to cleavage by trypsin over a wide dose range. ${ }^{125} \mathrm{I}-$ Factor XI was $\sim$ twofold more resistant to trypsin (data not shown). Thus, the proteolytic activity of the EC homogenate, unlike that of trypsin, appears to be relatively specific for HF.

Subcellular localization of the HF-cleaving activity. To determine whether the HF-cleaving activity was present in the cytosol or was associated with a sedimentable or particulate fraction of the cells, EC were disrupted by homogenization and subjected to differential centrifugation. A sedimentable particulate fraction and supernatant cytosol were isolated after centrifugation at $100,000 \mathrm{~g}$ for $60 \mathrm{~min}$ and analyzed for their capacity to cleave HF. As shown in Fig. 4, all HFcleaving activity present in the whole homogenate (lane 2) was recovered in the particulate fraction (lane 4), where total cleavage of ${ }^{125} \mathrm{I}-\mathrm{HF}$ into fragments of 28,000 and $31,000 M_{\mathrm{r}}$ were observed. No HFcleaving activity was detected in the cytosol (lane 3). Thus, the activity would appear to be predominantly associated with the microsomal fraction of the cells (e.g., plasma membrane, subcellular organelles, and other vesicles or secretion granules).

\section{Evidence that HF is activated by EC homogenate}

Prekallikrein cleavage and activation by activated $H F\left(H F_{\mathrm{a}}\right)$ generated by the EC homogenate. To demonstrate that the EC homogenate not only proteolytically cleaved but also activated HF molecules, the EC homogenate was incubated with native singlechain HF. This HF was then assessed for its ability to cleave prekallikrein. As shown in Fig. 5, the HF alone (lane 1) or EC homogenate alone (lane 2) caused no detectable proteolytic cleavage of prekallikrein. However, when both the EC homogenate and HF were present, extensive proteolytic cleavage of ${ }^{125}$ I-prekallikrein was observed (lane 3). The resulting fragments of 33,000 and $48,000 M_{\mathrm{r}}$ were similar to those observed when ${ }^{125} \mathrm{I}$-prekallikrein was present in kaolin-activated plasma.

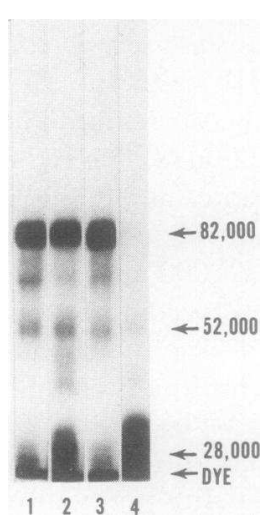

Figure 4 Autoradiogram demonstrating subcellular localization of HF-cleaving activity. ${ }^{125} \mathrm{I}-\mathrm{HF}$ ( $100 \mathrm{ng}$ ) was incubated in a final volume of $21 \mu \mathrm{l}$ for $10 \mathrm{~min}$ at $37^{\circ} \mathrm{C}$ in the presence of $0.1 \mathrm{M}$ Tris buffer, $\mathrm{pH} 7.6$, containing bovine serum albumin $(1 \mathrm{mg} / \mathrm{ml})$ (lane 1), buffer and the whole EC homogenate $(31 \mu \mathrm{g})$ (lane 2$)$, buffer with the 100,000-g supernate $(12 \mu \mathrm{g})$ (lane 3$)$, or buffer with the $100,000-g$ pellet $(45 \mu \mathrm{g})$ (lane 4). The mixtures were analyzed by SDS-PAGE and autoradiography. 


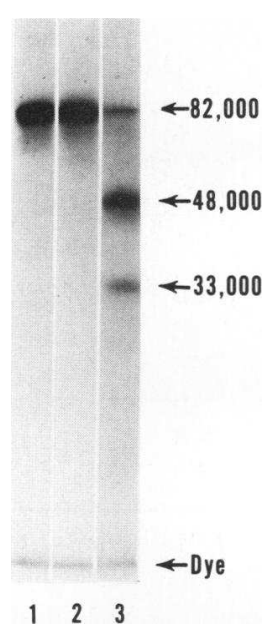

FIGURE 5 SDS-PAGE autoradiogram of ${ }^{125}$ I-prekallikrein incubated in the presence of $\mathrm{HF}$ and EC homogenate. ${ }^{125} \mathrm{I}$ prekallikrein $(160 \mathrm{ng}$ ) in $5 \mu \mathrm{l}$ of $0.1 \mathrm{M}$ Tris buffer, pH 7.4 , containing bovine serum albumin $(1 \mathrm{mg} / \mathrm{ml})$ was incubated for $10 \mathrm{~min}$ at $37^{\circ} \mathrm{C}$ in the presence of $\mathrm{HF}(300 \mathrm{ng}$ ) alone (lane 1), the EC homogenate alone ( $45 \mu \mathrm{g}$ of cellular protein) (lane 2 ), or both $\mathrm{HF}$ and the EC homogenate (lane 3 ). The reaction volumes $(22 \mu \mathrm{l})$ were equalized by addition of TBSaline and analyzed by SDS-PAGE and autoradiography.

A similar experiment was conducted in a plasma system (Fig. 6). When the EC homogenate was incubated with normal rabbit plasma to which ${ }^{125}$ Iprekallikrein had been added, $18 \%$ of the ${ }^{125} \mathrm{I}$-prekallikrein was cleaved, resulting in the formation of fragments of 33,000 and $48,000 M_{\mathrm{r}}$ (lane 3 ). In rab-

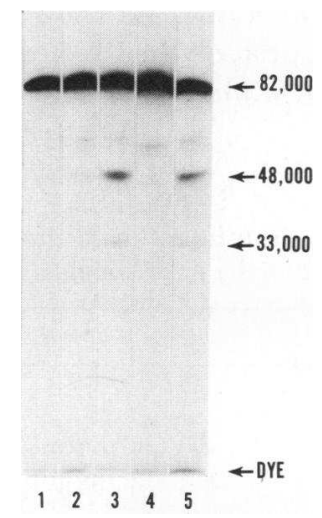

FIGURE 6 SDS-PAGE autoradiograms of ${ }^{125}$ I-prekallikrein in plasma. ${ }^{125} \mathrm{I}$-prekallikrein (160 $\mathrm{ng}$ ) was incubated for $10 \mathrm{~min}$ at $37^{\circ} \mathrm{C}$ in various rabbit plasmas $(12 \mu \mathrm{l}$ of $50 \%$ rabbit plasma in TBS) in the presence or absence of the EC homogenate (100 $\mu$ g of cellular protein). ${ }^{125 I-P r e k a l l i k r e i n ~ w a s ~ i n c u b a t e d ~}$ in normal rabbit plasma (lane 1) or $\mathrm{HF}$-depleted rabbit plasma reconstituted with purified HF (lane 2). EC homogenate was incubated with ${ }^{125}$ I-prekallikrein in the normal rabbit plasma (lane 3), in the HF-depleted plasma (lane 4), and in HF-depleted plasma reconstituted with purified $\mathrm{HF}$ (lane 5). bit plasma from which the $\mathrm{HF}$ had been specifically removed by immunoabsorption (see Methods), ${ }^{125} \mathrm{I}$ prekallikrein remained uncleaved after incubation with the EC homogenate (lane 4). However reconstitution of the HF-depleted plasma with purified $\mathrm{HF}$ resulted in cleavage of $25 \%$ of the ${ }^{125}$ I-prekallikrein (lane 5). ${ }^{125}$ I-Prekallikrein incubated in the normal rabbit plasma or reconstituted HF-depleted plasma alone resulted in no detectable cleavage (lanes 1 and 2). Thus, both in a partially purified system and in plasma, the EC homogenate converted HF to a form that proteolytically cleaved prekallikrein.

To confirm that the observed cleavage of radiolabeled molecules was indeed associated with the acquisition of activity, the ability of kallikrein (generated by EC homogenate $-\mathrm{HF}_{\mathrm{a}}$ ) to release kinin from purified rabbit high $M_{\mathrm{r}}$ kininogen was measured by bioassay (Table I). No detectable kinin activity was generated by single-chain $\mathrm{HF}$ incubated with prekallikrein and high $M_{\mathrm{r}}$ kininogen. In contrast, the addition of the EC homogenate (with $60 \mu \mathrm{g}$ of angiotensin-converting enzyme inhibitor) caused contraction of the rat uterus, with a response time equivalent to that of $18 \mathrm{ng}$ of bradykinin. Preliminary studies had shown that bradykinin was destroyed when incubated with the EC homogenate alone, and that this effect could be inhibited by a 1,000 -fold $M$ excess of the angiotensin-converting enzyme inhibitor SQ 20,881. Furthermore, the inhibitor itself, at this dose, had no agonistic effect on the rat uterus, and incubation of the rat uterus in the presence of the inhibitor did not subsequently alter the sensitivity of the uterus to bradykinin. We, therefore, conclude from this study that the EC homogenate was capable of activating $\mathrm{HF}$ to activate prekallikrein to kallikrein, which then released kinin from high $M_{\mathrm{r}}$ kininogen. These findings complement the cleavage data described above.

Factor XI cleavage by $H F_{\text {a }}$ generated by the EC homogenate. To further characterize the activity associated with EC-cleaved $\mathrm{HF}$, the ability of a mixture of $\mathrm{HF}$ and EC homogenate to cleave another HF substrate, Factor XI, was evaluated (Fig. 7). Native ${ }^{125} \mathrm{I}$ Factor XI (lane 1) was cleaved slightly in the presence of high $M_{\mathrm{r}}$ kininogen and a kaolin surface (lane 2), and the addition of the EC homogenate to this mixture had no effect (lane 3). Addition of HF to the ${ }^{125} \mathrm{I}$-Factor XI-high $M_{\mathrm{r}}$ kininogen-kaolin mixture resulted in cleavage of only $9 \%$ of the ${ }^{125} \mathrm{I}$-Factor XI molecules (lane 4). However, when the EC homogenate was added to the latter mixture in the presence of $\mathrm{HF}$, as much as $46 \%$ of the ${ }^{125} \mathrm{I}$-Factor XI molecules were cleaved (lane 5). The cleavage fragments generated at 50,000 and 33,000 $M_{\mathrm{r}}$ migrated at the same position as those observed when ${ }^{125} \mathrm{I}$ Factor XI was present in kaolin-activated rabbit plasma. Removal of high $M_{\mathrm{r}}$ kininogen from the above 
TABLE I

Kinin Generation by Purified Proteins of the HF-System in the Presence of EC Homogenate

\begin{tabular}{|c|c|c|c|c|c|c|}
\hline $\begin{array}{c}\alpha-\mathrm{HF}_{\mathrm{a}} \\
(1.5 \mu \mathrm{g})\end{array}$ & $\begin{array}{c}\text { HF } \\
(1.6 \mu \mathrm{g})\end{array}$ & $\begin{array}{c}\text { EC } \\
\text { homogenate } \\
(220 \mu \mathrm{g})\end{array}$ & $\begin{array}{l}\text { Prekallikrein } \\
\qquad(2 \mu \mathrm{g})\end{array}$ & $\begin{array}{l}\text { High } M_{\mathrm{r}} \\
\text { kininogen } \\
\quad(5 \mu \mathrm{g})\end{array}$ & $\begin{array}{c}\text { Response } \\
\text { time }\end{array}$ & $\begin{array}{l}\text { Bradykinin } \\
\text { equivalent }\end{array}$ \\
\hline & & & & & $s$ & $n g$ \\
\hline- & + & + & + & + & 3.5 & 18 \\
\hline- & + & - & + & + & NR & $<4$ \\
\hline- & - & + & + & + & NR & $<4$ \\
\hline- & + & + & - & + & NR & $<4$ \\
\hline- & - & - & + & + & NR & $<4$ \\
\hline+ & - & - & + & + & 3.0 & 22 \\
\hline
\end{tabular}

$\mathrm{HF}, \boldsymbol{\alpha}-\mathrm{HF}_{\mathrm{a}}$, and the EC homogenate (with angiotensin-converting enzyme inhibitor SQ 20881)

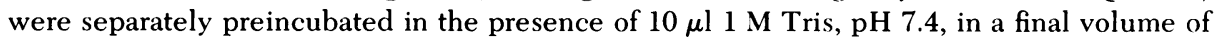
$50 \mu \mathrm{l}$ in a polypropylene tube for $5 \mathrm{~min}$ at $37^{\circ} \mathrm{C}$. Prekallikrein (or $10 \mu \mathrm{l} 0.1 \mathrm{M}$ Tris buffer, $\mathrm{pH}$ 7.4) was added to each tube for $3 \mathrm{~min}$ at $37^{\circ} \mathrm{C}$. Finally, high $M_{\mathrm{r}}$ kininogen $(50 \mu \mathrm{l})$ was added and incubated for $10 \mathrm{~min}$ at $37^{\circ} \mathrm{C}$. The reaction was stopped by boiling for $4 \mathrm{~min}$, and the kinin generated was measured by bioassay using an estrogen-sensitized rat uterus (see Methods). NR, no response.

reaction mixture reduced the proteolytic cleavage to $12 \%$ (lane 6), a proportion only slightly greater than that seen with $\mathrm{HF}$ in the absence of EC homogenate (lane 4). The EC homogenate, therefore, contains a molecule(s) that can convert HF to a form capable of cleaving both prekallikrein and Factor XI.

\section{Effect of protease inhibitors in HF-cleaving activity of EC homogenate}

Diisopropylfluorophosphate. The addition of diisopropylfluorophosphate $(2 \mathrm{mM})$ to the EC homog-

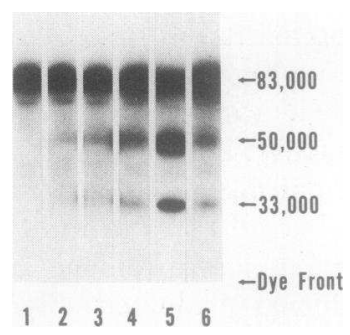

FIGURE 7 SDS-PAGE autoradiograms of ${ }^{125}$ I-Factor XI incubated with various agents. ${ }^{125} \mathrm{I}$-Factor XI $(80 \mathrm{ng})$ was added to $5 \mu \mathrm{l}$ of $0.1 \mathrm{M}$ Tris, $\mathrm{pH} 7.4$, containing bovine serum albumin $(1 \mathrm{mg} / \mathrm{ml}$ ) and kaolin $(50 \mu \mathrm{g}$ TBS). To this mixture was added HF (300 ng), high $M_{\mathrm{r}}$ kininogen (400 ng), or EC homogenate ( $55 \mu \mathrm{g}$ of cellular protein). The final reaction volume was made up to $40 \mu$ l with TBS. After 15 $\min$ at $37^{\circ} \mathrm{C}$, the samples were analyzed by SDS-PAGE and autoradiography. ${ }^{125} I-F$ actor $X I$ was incubated in the presence of kaolin alone (lane 1 ), kaolin and high $\boldsymbol{M}_{\mathrm{r}}$ kininogen (lane 2), kaolin, high $M_{\mathrm{r}}$ kininogen, and the EC homogenate (lane 3). HF was added to kaolin and high $M_{r}$ kininogen in the absence (lane 4) and presence of EC homogenate (lane 5). The effect of the absence of high $M_{\mathrm{r}}$ kininogen from the above reaction mixture $(\mathrm{HF}$, kaolin, and EC) is shown in lane 6. enate for $5 \mathrm{~min}$ at $22^{\circ} \mathrm{C}$ abolished the cell-associated HF-cleaving activity (Table II, A), suggesting that the enzyme in the EC homogenate responsible for $\mathrm{HF}$ cleavage is a serine protease.

Soybean trypsin inhibitor (SBTI). Because the HFcleaving activity could have been the result of contamination of the homogenate by residual tissue culture trypsin, the sensitivity of the EC enzyme to SBTI was assessed. As shown in Table II (B) the EC enzyme was insensitive to SBTI, whereas trypsin, at a dose that cleaved $99 \%$ of the ${ }^{125} \mathrm{I}-\mathrm{HF}$ molecules, was completely inhibited by SBTI.

Thrombin and hirudin. As shown in Table II (C) thrombin did not proteolytically cleave ${ }^{125} \mathrm{I}-\mathrm{HF}$, even at a relatively high final concentration of $10 \mathrm{U} / \mathrm{ml}$.

TABLE II

Effect of Protease Inhibitors on Cleavage of Hageman Factor by EC Homogenate

\begin{tabular}{llr}
\hline \multicolumn{1}{c}{ Inhibitor } & \multicolumn{1}{c}{ Activator } & HF cleaved \\
& & $\%$ \\
A DFP* $(2 \mathrm{mM})$ & EC $(11 \mathrm{mg} / \mathrm{ml})$ & 0 \\
None & EC $(11 \mathrm{mg} / \mathrm{ml})$ & 62 \\
B SBTI $(50 \mu \mathrm{g} / \mathrm{ml})$ & EC $(11 \mathrm{mg} / \mathrm{ml})$ & 61 \\
None & EC $(11 \mathrm{mg} / \mathrm{ml})$ & 62 \\
SBTI $(50 \mu \mathrm{g} / \mathrm{ml})$ & Trypsin $(25 \mu \mathrm{g} / \mathrm{ml})$ & 3 \\
None & Trypsin $(25 \mu \mathrm{g} / \mathrm{ml})$ & 99 \\
C Hirudin $(20 \mathrm{U} / \mathrm{ml})$ & EC $(8 \mathrm{mg} / \mathrm{ml})$ & 94 \\
None & EC $(8 \mathrm{mg} / \mathrm{ml})$ & 96 \\
Hirudin $(20 \mathrm{U} / \mathrm{ml})$ & Thrombin $(10 \mathrm{U} / \mathrm{ml})$ & 4 \\
None & Thrombin $(10 \mathrm{U} / \mathrm{ml})$ & 6 \\
\hline
\end{tabular}

* Diisopropylfluorophosphate. 
Hirudin also did not block the EC-mediated HF cleavage. Thus, the responsible enzyme in the EC homogenate does not appear to be thrombin.

\section{Effect of antisera to $H F$, kallikrein, and plasmin on HF-cleaving activity}

As shown in Table III, cleavage of ${ }^{125} \mathrm{I}-\mathrm{HF}$ by the EC enzyme derived from cells cultured for $3 \mathrm{~d}$ in rabbit serum was not inhibited by the IgG fraction of antisera raised against rabbit kallikrein or rabbit plasmin, nor by the IgG fraction of preimmune goat serum. However, the IgG fraction of anti-rabbit HF blocked $\mathrm{HF}$ cleavage. As a positive control for these experiments, we demonstrated that cleavage of $\mathrm{HF}$ by kallikrein was completely inhibited by antikallikrein IgG. In other experiments (not shown), the antiplasmin antiserum has been shown to inhibit plasmin activity. These results indicate that the EC enzyme is neither kallikrein nor plasmin, which is consistent with the finding that the EC enzyme was not inhibited by SBTI (Table II, B), a molecule that inhibits both kallikrein and plasmin (18).

\section{Effect of Triton X-100, hexadimethrine bromide (Polybrene), and kaolin on $\mathrm{HF}$ cleavage by the EC homogenate}

Incubation of the EC homogenate with Triton $\mathrm{X}-100$ or Polybrene for $10 \mathrm{~min}$ at $22^{\circ} \mathrm{C}$ had no effect upon the extent of $\mathrm{HF}$ cleavage. (EC homogenate alone and EC homogenate with Triton X-100 [0.5\%] cleaved 90 and $86 \%$ of ${ }^{125} \mathrm{I}-\mathrm{HF}$, respectively; EC homogenate alone and EC homogenate with Polybrene cleaved 23 and $25 \%$ of ${ }^{125} \mathrm{I}-\mathrm{HF}$, respectively.) Thus, cleavage by EC homogenate does not appear to be simply the result of a surface effect. Furthermore, preincubation of the ${ }^{125} \mathrm{I}-\mathrm{HF}$ with kaolin enhanced the cleavage of $\mathrm{HF}$ in the presence of the EC homogenate $\sim 10$-fold. (EC homogenate $[1.0 \mathrm{mg} / \mathrm{ml}]$ alone, EC homogenate $[1.0 \mathrm{mg} / \mathrm{ml}]$ with kaolin [2.5 $\mathrm{mg} / \mathrm{ml}]$, and EC homogenate $[0.125 \mathrm{mg} / \mathrm{ml}]$ with

TABLE III

Effect of Antisera on Cleavage of Hageman Factor by EC Homogenate

\begin{tabular}{llr}
\hline \multicolumn{1}{c}{ IgG fraction } & \multicolumn{1}{c}{ Activator } & HF cleaved \\
\hline & & $\%$ \\
Normal goat serum & EC $(5 \mathrm{mg} / \mathrm{ml})$ & 57 \\
Anti-HF & EC $(5 \mathrm{mg} / \mathrm{ml})$ & 0 \\
Antiplasmin & EC $(5 \mathrm{mg} / \mathrm{ml})$ & 69 \\
Antikallikrein & EC $(5 \mathrm{mg} / \mathrm{ml})$ & 63 \\
Antikallikrein & Kallikrein $(5 \mu \mathrm{g} / \mathrm{ml})$ & 0 \\
Normal goat serum & Kallikrein $(5 \mu \mathrm{g} / \mathrm{ml})$ & 48 \\
\hline
\end{tabular}

kaolin $[2.5 \mathrm{mg} / \mathrm{ml}]$ cleaved 20,77 , and $15 \%$ of ${ }^{125} \mathrm{I}-\mathrm{HF}$, respectively.)

\section{HF-cleaving activity associated with other cultured vascular cells}

Cell homogenates prepared from two other cultured cell types from rabbit aorta were assessed for their ability to proteolytically cleave ${ }^{125} \mathrm{I}-\mathrm{HF}$. Under the conditions under which the EC homogenate at $3 \mathrm{mg} / \mathrm{ml}$ cellular protein concentration cleaved $43 \%$ of the ${ }^{125} \mathrm{I}-\mathrm{HF}$, a homogenate prepared from cells with the cytological features of smooth muscle cells (14) at a concentration of $3.4 \mathrm{mg} / \mathrm{ml}$ cleaved $33 \%$ of the ${ }^{125} \mathrm{I}-\mathrm{HF}$ molecules. A second cell line derived from rabbit aorta and thought to represent rabbit intimal cells cleaved $30 \%$ of the ${ }^{125} \mathrm{I}-\mathrm{HF}$ molecules when present at a concentration of $2.8 \mathrm{mg} / \mathrm{ml}$. The relative $\mathrm{HF}$ cleaving activities of the two-cell homogenates was, therefore, similar to that of the endothelial cell homogenate, and similar cleavage fragments were generated, suggesting that the HF-cleaving enzyme is not restricted to endothelial cells.

\section{DISCUSSION}

Activation of $\mathrm{HF}$ can initiate coagulation via activation of Factor XI (19-22) or Factor VII (23-25). HF $_{\mathrm{a}}$ proteolytically converts prekallikrein to kallikrein, leading to plasmin generation $(26,27)$, the release of the vasoactive peptide bradykinin from high $M_{r}$ kininogen (28), and activation of the renin-angiotensin system (29). The mechanism by which this potentially powerful HF-dependent mediator system in activated in vivo remains to be elucidated. Artificial, negatively charged substances such as glass, kaolin, or celite activate the plasma system in vitro. Some collagen and basement membrane preparations $(30,31)$, bacterial endotoxins (32), and urate crystals (33) may serve as activating surfaces in physiological or pathophysiological situations. However, the manner by which HF is activated in vivo and the role of the negatively charged surface in this process remain conjectural.

The results summarized in this report indicate that cultured EC contain an enzyme that cleaves and activates HF. The EC activity appears to be relatively specific for $\mathrm{HF}$ because, under the experimental conditions explored, neither prekallikrein nor Factor XI were readily cleaved when separately incubated with the EC homogenate. Because diisopropylfluorophosphate abolished HF cleavage by the EC homogenate, it appears that a serine protease is responsible for this activity. Surface binding of HF renders it much more susceptible to cleavage by a number of enzymes (34). Because neither Triton X-100 nor hexadimethrine bromide (Polybrene) diminished the 
HF-cleaving activity of the cell homogenate, and because kaolin enhanced this activity, it seems unlikely that the presence of negatively charged material in the cell homogenate rendered HF more susceptible to enzymatic cleavage. Proteolysis of HF by the enzyme was demonstrated both in a purified system and in plasma. A principle cleavage fragment generated from HF by the EC enzyme was the $28,000 M_{\mathrm{r}}$ fragment. This appears to be the same fragment that is generated during activation of $\mathrm{HF}$ in kaolin-activated plasma, and is probably the fragment that has been shown to contain the active site of $\mathrm{HF}$ (35). That the HF is activated as well as proteolytically cleaved by the EC homogenate is evident from the ability of $\mathrm{HF}$ to subsequently cleave its substrate molecules - Factor XI and prekallikreinat cleavage sites apparently identical to those observed when these molecules are cleaved and activated in purified reaction mixtures and in kaolin-activated rabbit plasma $(10,22)$. Furthermore, $\mathrm{HF}_{\mathrm{a}}$ generated by the EC homogenate was also shown to activate prekallikrein to kallikrein and, thus, to release kinin from high $M_{\mathrm{r}}$ kininogen as measured by a rat uterus bioassay system. Finally, activation of HF was not only demonstrated in the partially purified system, but also in rabbit plasma. We conclude from these observations that cultured rabbit EC possess the capability to activate $\mathrm{HF}$ by proteolysis.

In preliminary studies, a similar HF-cleaving enzyme was detected in cultured aortic smooth muscle and intimal cells. Thus, it would appear that this enzyme is not restricted to endothelial cells, but like tissue factor (36), is present in other types of vascular cells.

The capacity of the EC-activated HF to cleave both prekallikrein and Factor XI is of interest with respect to the observed cleavage fragments of HF. Studies of the human $\mathrm{HF}$ system suggest that the free $28,000 M_{\mathrm{r}}$ form of $\mathrm{HF}_{\mathrm{a}}\left(\beta-\mathrm{HF}_{\mathrm{a}}\right)$ is much more capable of activating prekallikrein than Factor XI, whereas the $82,000 M_{\mathrm{r}}$ form of $\mathrm{HF}_{\mathrm{a}}\left(\alpha-\mathrm{HF}_{\mathrm{a}}\right)$, which binds to negatively charged surfaces, is capable of activating both prekallikrein and Factor XI $(37,38)$. In the present studies of the cleavage of $\mathrm{HF}$ in solution by the EC homogenate, the dominant form of $\mathrm{HF}_{\mathrm{a}}$ generated was the $28,000 M_{\mathrm{r}}$ form $\beta-\mathrm{HF}_{\mathrm{a}}$. It was therefore expected, and confirmed, that this material could indeed cleave prekallikrein. The finding that, in the presence of kaolin and high $M_{\mathrm{r}}$ kininogen, Factor XI could also be activated by EC-generated $\mathrm{HF}_{\mathrm{a}}$ is consistent with our observation that kaolin-bound $\mathrm{HF}$ was cleaved by the EC extract to yield the 52,000 and $28,000 M_{\mathrm{r}}$ fragments of the surface-bound $\alpha-\mathrm{HF}_{\mathrm{a}}$. The marked requirement for high $M_{\mathrm{r}}$ kininogen for Factor XI activation emphasizes the role of this cofactor mole- cule in placing the Factor XI on an appropriate surface where it can be activated by $\alpha-\mathrm{HF}_{\mathrm{a}}(12,39)$.

The possibility that the cells contain a trypsinlike enzyme or were contaminated by trypsin from prior passage was excluded by showing that the relative sensitivity of $\mathrm{HF}$, Factor XI, and prekallikrein to the EC enzyme was quite different from that of trypsin. In addition, it was shown that the EC enzyme, unlike trypsin, was not inhibited by SBTI. Several other possible HF-cleaving enzymes were considered as sources of the observed HF-cleaving activity. Kallikrein, plasmin, or thrombin (from serum used in the growth medium or produced de novo by the cultured cells) might conceivably have caused the observed HF cleavage. However, thrombin was shown not to cleave $\mathrm{HF}$, and kallikrein and plasmin were excluded both by using specific antisera against these components and by the resistance of cleavage to an inhibitor (SBTI) that inhibits kallikrein and plasmin (18). Thus, not only were extraneous kallikrein or plasmin excluded as the causal agent of $\mathrm{HF}$ cleavage, but also the possibility that the cultured EC might themselves synthesize these enzymes was excluded.

The HF-cleaving enzyme appeared to be associated with some structural element of the cell because it was recovered in the particulate fraction after centrifugation of cell homogenate at $100,000 \mathrm{~g}$. Studies are at present directed toward establishing whether the enzyme is associated with cell membrane, cellular organelles, or subendothelial structures. A plasminogen activator has been shown to be produced by EC cells (1). It is also inhibited by diisopropylfluorophosphate, and can be sedimented with the particulate fraction of the cells. These observations raise the possibility that the HF-cleaving and plasminogenactivating enzymes might be identical. Further studies are in progress to investigate the relationship between these activities.

Endothelial cells are known to produce enzymes that activate plasminogen $(1,2)$, procoagulant molecules such as tissue factor (36), and factors that influence platelet function and vascular tone $(3-7)$. We now report the capacity of this cell type to activate HF. Whether this activity can be released from stimulated or damaged EC into the surrounding medium, or whether it remains associated with the corpse of the injured cell must be determined. However, if the HF-cleaving activity is exposed when EC or deeper layers are damaged, HF activation should occur. Furthermore, damage to the EC layer might expose subcellular structures with a sufficient density of negative charges to facilitate assembly of the surfacebound HF-high $M_{\mathrm{r}}$ kininogen-Factor XI-prekallikrein complexes similar to the one demonstrated for kaolin $(12,39,40)$. Under these circumstances, the 
EC enzyme could initiate HF cleavage, an essential step for the reciprocal activation between $\mathrm{HF}$ and prekallikrein (41). This may be one mechanism by which $\mathrm{HF}$ is activated in vivo.

\section{ACKNOWLEDGMENTS}

The authors wish to acknowledge the excellent technical assistance of B. Loskutoff and David Revak and the willing secretarial assistance of Margaret Stone and Betty Goddard.

This work was supported in part by training grant HL07195 and research grants HL-16411, AI-07007 from the National Institutes of Health, the Council of Tobacco Research, and Research Career Development Award HL-00192 to J.H.G.

\section{REFERENCES}

1. Loskutoff, D. J., and T. S. Edgington. 1977. Synthesis of a fibrinolytic activator and inhibitor by endothelial cells. Proc. Natl. Acad. Sci. U. S. A. 74: 3903-3907.

2. Warren, B. A. 1964. Fibrinolytic activity of vascular endothelium. Br. Med. Bull. 20: 213-216.

3. Weksler, B. B., A. J. Marcus, and E. A. Jaffe. 1977. Synthesis of prostaglandin $\mathrm{I}_{2}$ (prostacyclin) by cultured human and bovine endothelial cells. Proc. Natl. Acad. Sci. U. S. A. 74: 3922-3926.

4. Saba, S. R., and R. G. Mason. 1974. Studies on an activity from endothelial cells that inhibits platelet aggregation, serotonin release and clot retraction. Thromb. Res. 5: 747-757.

5. Dosne, A. M., C. Legrand, B. Bauvois, E. Bodevin, and J. P. Caen. 1978. Comparative degradation of adenylnucleotides by cultured endothelial cells and fibroblasts. Biochem. Biophys. Res. Commun. 85: 183-194.

6. Gibrone, M. A., Jr., and R. W. Alexander. 1975. Angiotensin II stimulation of prostaglandin production in cultured human vascular endothelium. Science (Wash.D.C.). 189: $219-220$.

7. Mason, R. G., D. Sharp, H. Y. K. Chuang, and F. Mohammad. 1977. The endothelium. Roles in thrombosis and hemostasis. Arch. Pathol. Lab. Med. 101: 61-64.

8. Griffin, J. H., and C. G. Cochrane. 1976. Human Factor XII (Hageman factor). Methods Enzymol. 45: 56-65.

9. Griffin, J. H. 1976. Purification and properties of human and rabbit Hageman factor (coagulation Factor XII). Fed. Proc. 35: 1764.

10. Ulevitch, R. J., C. G. Cochrane, and A. R. Johnston. 1979. Rabbit prekallikrein: the purification, biochemical characterization and mechanism of activation. Inflammation. In press.

11. Wiggins, R. C., C. G. Cochrane, and J. H. Griffin. 1979. Rabbit coagulation Factor XI. Purification and characterization. Thromb. Res. 15: 475-486.

12. Wiggins, R. C., B. Bouma, C. G. Cochrane, and J. H. Griffin. 1977. Role of high-molecular-weight kininogen in surface-binding and activation of coagulation Factor XI and prekallikrein. Proc. Natl. Acad. Sci. U. S. A. 74: $4636-4640$.

13. Gibron, M. A. 1976. Culture of vascular endothelium. Prog. Hemostasis Thromb. 3: 1-28.

14. Ross, R. 1971. The smooth muscle cell. II. Growth of smooth muscle in culture and formation of elastic fibers. J. Cell Biol. 50: 172-186.

15. Laemmli, U. K. 1970. Cleavage of structural proteins during the assembly of the head of bacteriophage T4. Nature (Lond.). 227: 680-685.
16. Lowry, O. H., R. J. Rosebrough, A. L. Farr, and R. J. Randall. 1951. Protein measurement with the Folin phenol reagent. J. Biol. Chem. 193: 265-275.

17. McConahey, P. J., and F. J. Dixon. 1966. A method of trace iodination of proteins for immunologic studies. Int. Arch. Allergy Appl. Immunol. 29: 185-189.

18. Kassell, B. 1970. Trypsin and chymotrypsin inhibitors from soybeans. Methods Enzymol. 19: 835-862.

19. Ratnoff, O. D., E. W. Davie, and D. L. Mallet. 1961. Studies on the action of Hageman factor: evidence that activated Hageman factor in turn activates plasma thromboplastin antecedent. J. Clin. Invest. 40: 803-819.

20. Bouma, B. N., and J. H. Griffin. 1977. Human blood coagulation Factor XI. Purification, properties and mechanism of activation by activated Factor XII. J. Biol. Chem. 25: 6432-6437.

21. Koide, T., H. Kato, and E. W. Davie. 1977. Isolation and characterization of bovine Factor XI (plasma thromboplastin antecedent). Biochemistry. 16: 2279-2286.

22. Wiggins, R. C., C. G. Cochrane, and J. H. Griffin. 1979. Rabbit Factor XI. Mechanism of activation by rabbit Hageman factor (Factor XII). Thromb. Res. 15: 487-495.

23. Rapaport, S. I., K. Aas, and P. A. Owren. 1955. The effect of glass upon the activity of the various clotting factors. J. Clin. Invest. 34: 9-19.

24. Laake; K., and B. Osterud. 1974. Activation of purified Factor VII by human plasmin, plasma kallikrein, and activated components of the human intrinsic blood coagulation system. Thromb. Res. 5: 759-772.

25. Kisiel, W., K. Fujikawa, and E. W. Davie. 1977. Activation of bovine Factor VII (proconvertin) by Factor XII $_{\mathrm{a}}$ (activated Hageman factor). Biochemistry. 16: 4189-4194.

26. Bouma, B. N., and J. H. Griffin. 1978. Deficiency of Factor XII-dependent plasminogen proactivator in prekallikrein-deficient plasma. J. Lab. Clin. Med. 91: 148155.

27. Mandle, R., Jr., and A. P. Kaplan. 1977. Hageman factor substrates. Human plasma prekallikrein: mechanism of activation by Hageman factor and participation of Hageman factor-dependent fibrinolysis. J. Biol. Chem. 252: 6097-6104.

28. Han, Y. N., H. Kato, H. Iwanaga, and T. Suzuki. 1976. Primary structure of bovine plasma high-molecularweight-kininogen. The amino acid sequence of a glycoprotein portion (Fragment 1 ) following the C-terminus of the bradykinin moiety. J. Biochem. (Tokyo) 79: 12011222.

29. Sealey, J. E., M. Silverberg, J. M. Laraugh, S. A. Atlas, and A. P. Kaplan. 1979. Activation of plasma prorenin by enzymes of the coagulation and fibrinolytic systems. Fed. Proc. 38: 2369. (Abstr.)

30. Soltay, M. J., H. Z. Movat, and A. H. Ozge-Anwar. 1971. The kinin system of human plasma. V. The probable derivation of prekallikrein activator from activated Hageman factor $\left(\mathrm{XII}_{\mathrm{a}}\right)$. Proc. Soc. Exp. Biol. Med. 138: $952-966$.

31. Cochrane, C. G., S. D. Revak, B. S. Aiken, and K. D. Wuepper. 1972. The structural characteristic and activation of Hageman factor. In Inflammation, Mechanisms and Control. I. M. Lepow, and P. A. Ward, editors. Academic Press, Inc., New York. 119-150.

32. Morrison, D. C., and C. G. Cochrane. 1974. Direct evidence for Hageman factor (Factor XII) activation by bacterial lipopolysaccharides (endotoxins). J. Exp. Med. 140: $797-811$. 
33. Kellermeyer, R. W., and R. T. Breckenridge. 1965. The inflammatory process in acute gouty arthritis. I. Activation of Hageman factor by sodium urate crystals. $J$. Lab. Clin. Med. 65: 307-315.

34. Griffin, J. H. 1978. The role of surface in the surfacedependent activation of Hageman factor (Factor XII). Proc. Natl. Acad. Sci. U. S. A. 75: 1998-2002.

35. Revak, S. D., and C. G. Cochrane. 1976. The relationship of structure and function in human Hageman factor. The association of enzymatic and binding activities with separate regions of the molecule. J. Clin. Invest. 57: $852-860$.

36. Maynard, J. R., B. E. Dreyer, M. B. Stemerman, and F. A. Pitlick. 1977. Tissue-factor coagulant activity of cultured human endothelial and smooth muscle cells and fibroblasts. Blood. 50: 387-396.

37. Kaplan, A. P., and K. F. Austen. 1971. A prealbumin activator of prekallikrein. II. Derivation of activators of prekallikrein from active Hageman factor by digestion with plasmin. J. Exp. Med. 133: 896-712.

38. Revak, S. D., C. G. Cochrane, B. N. Bouma, and J. H. Griffin. 1978. Surface and fluid phase activities of two forms of activated Hageman factor produced during contact activation in plasma. J. Exp. Med. 147: 719-729.

39. Thompson, R. E., R. Mandle, Jr., and A. P. Kaplan. 1977. Association of Factor XI and high molecular weight kininogen in human plasma. J. Clin. Invest. 66: 1376-1380.

40. Mandle, R., Jr., R. W. Colman, and A. P. Kaplan. 1976. Identification of prekallikrein and high MW kininogen as a complex in human plasma. Proc. Natl. Acad. Sci. U. S. A. 73: 4179-4183.

41. Cochrane, C. G., S. D. Revak, and K. D. Wuepper. 1973. Activation of Hageman factor in solid and fluid phases. A critical role of kallikrein. J. Exp. Med. 138: 15641583. 